\title{
PULMONARY OSSIFIC NODULES IN MITRAL VALVE DISEASE
}

\author{
BY \\ R. W. GALlOWAY, E. J. EPSTEIN, AND N. COULSHED \\ From the Liverpool Regional Cardiac Centre and the Department of Radiology, Sefton General Hospital, \\ Liverpool \\ Received July 18, 1960
}

Bone formation in the lungs was first reported by Wagner in 1859, although its relationship to mitral valve disease was not recognized until 1932 by Salinger. In the past few years several papers about this lesion have appeared reporting small groups of patients or isolated cases (Wells and Dunlap, 1943; Grishman and Kane, 1945; Steiner and Goodwin, 1954; Short, 1955; Daugavietis and Mautner, 1957). The two most comprehensive are those by Whittaker et al. (1955) and Fleming and Robinson (1957). As a rule patients with radiological evidence of pulmonary ossific nodules are men, 20 to 40 years of age, with mitral stenosis, pulmonary arterial hypertension, and often with calcification of the mitral valve.

In a recent clinical and radiological review of mitral valve disease we noticed that ossific nodules were seen not infrequently on the chest films. We therefore thought it worthwhile reviewing these films to assess their incidence and at the same time to evaluate any factors of clinical significance.

Previous observers have commented on the rarity of this finding and on the large preponderance in men. The purpose of this paper is to show that this lesion is by no means rare on radilogical examination and, if carefully sought for, particularly by histological means at post-mortem, it may prove to be a fairly common finding. This being so, it would follow that the cause of the nodules is not to be sought in some rare unspecified complication of mitral valve disease, but probably in a well recognized major physio-pathological disturbance.

\section{PRESENT INVESTIGATION}

A survey was made of the chest films of a group of 204 patients admitted to the Regional Cardiac Centre for assessment of their mitral valve disease. A standard postero-anterior chest film and right and left anterior oblique views were available for assessment in all cases. The films were reviewed jointly by three observers and ossific nodules were considered to be present only when all the observers agreed. In several instances one person dissented and such films were classified as "doubtful" providing the other two supported their presence. If only one observer thought that nodules were present the film was excluded from the series.

There were eight further patients without radiological evidence of ossific nodules, who were not included in the survey. All died from their mitral valve disease, and at autopsy one lung was available from each patient for detailed examination, the other lung being kept for a separate investigation. The lung was divided into separate lobes, which were then cut into slices of approximately one centimetre thickness in the coronal plane. A contact X-ray film was made of each lung slice and carefully examined for the presence of ossific nodules. Sections were then examined from any suspicious area after preliminary decalcification. In addition blocks were taken at random mainly from the lower lobe and were examined in serial section for ossific or osteoid tissue. By this means it was hoped to find ossific nodules at different stages of development.

Out of the films examined from 204 patients there were 27 with definite ossific nodules and 9 
cases with "doubtful" nodules. Only the "definite" group has been used for analysis. Ossific nodules were found on histological examination in each of the eight patients examined at autopsy, although they were not demonstrated by routine radiology. They have not been included in this series as they died after the preliminary radiological and clinical survey had been completed.

\section{Clinical and Radiological Details}

Table I shows the sex distribution of the patients, and Table II gives the clinical and radiological findings in those with ossific nodules. Included in the 27 , were 14 men and 13 women. Thus,

TABLE I

The Sex Distribution of the Series With the Incidence of Ossific Nodules

\begin{tabular}{|c|c|c|c|c|c|c|}
\hline & & & & $\begin{array}{l}\text { Total No. of } \\
\text { patients }\end{array}$ & $\begin{array}{l}\text { No. of patients } \\
\text { with nodules }\end{array}$ & $\begin{array}{l}\text { Percentage with } \\
\text { ossific nodules }\end{array}$ \\
\hline Men & .. & .. & .. & 57 & 14 & $24 \cdot 5$ \\
\hline Women & .. & .. & .. & 147 & 13 & $8 \cdot 8$ \\
\hline Total & .. & .. & .. & 204 & 27 & $13 \cdot 2$ \\
\hline
\end{tabular}

the patients were evenly divided between the sexes, but in the series as a whole there were 147 women and 57 men, a ratio of female to male of $2 \cdot 5$ to 1 . Therefore, the incidence of ossific nodules was 13 per cent of patients taken as a whole, but in 25 per cent of men and 9 per cent of women. That is three times as frequently in men as in women.

The age of the patients varied from 24 to 52 years, the average age being $35 \cdot 7$ years for the group with nodules. For men the average age was 36.7 years and for women 35 years. In the series as a whole the average age was 37 years for men and 39.4 years for women. There were, therefore, no special features regarding the age of those patients with ossific nodules. A clear history of rheumatic fever or chorea was given by only 8 patients.

Paroxysmal nocturnal dyspnœa was present in over one-third (11 patients). This is of special interest as Fleming and Robinson (1957) specifically recorded the absence of this symptom in their 8 patients and it was present in only 2 of the 7 reported by Whittaker et al. (1955). Hæmoptysis had occurred in 18 of the 27 patients with nodules, but it did not appear to be more severe or more frequent than in other patients in the group as a whole. Congestive cardiac failure was present in 7 ( 4 women and 3 men) but without any special features.

Twenty of the 27 patients had cardiac catheterization studies performed. In 9 the pulmonary artery systolic pressure was $65 \mathrm{~mm}$. $\mathrm{Hg}$ or over, and in four of these the pressure was over $100 \mathrm{~mm}$. $\mathrm{Hg}$. The other 11 showed normal pressures in 4 (below $35 \mathrm{~mm}$. $\mathrm{Hg}$ systolic) and ranged from 40 to $55 \mathrm{~mm}$. in the other 7 patients. The mean pulmonary wedge pressure (indirect left atrial pressure) was measured in 17 and this was above normal in all but one being $20 \mathrm{~mm}$. Hg or more in 13 patients. Furthermore, septal lines were visible on 17 of the X-ray films assessed, and eleven patients gave a history of paroxysmal nocturnal dyspnœa. It is considered that each of the three findings of paroxysmal nocturnal dyspnœa, septal lines, and an indirect left atrial pressure above $20 \mathrm{~mm}$. $\mathrm{Hg}$ may be taken as evidence of pulmonary venous hypertension (Carmichael et al., 1954; Grainger and Hearn, 1955; Rossall and Gunning, 1956.) Twenty-four patients had at least one of the above findings and hence by inference had significant pulmonary venous hypertension.

Apart from the 17 patients showing septal lines, and hence radiological evidence of pulmonary venous hypertension, 9 showed vascular patterns in keeping with severe pulmonary arterial hypertension (Davies et al., 1953). The size of the nodules and the number of the lung field zones in which they were present could not be correlated with either the pulmonary artery pressure 
TABLE II

Details of the Clinical, Hamodynamic, and Radiological features in the Group of Patients with Ossific NODULES

\begin{tabular}{|c|c|c|c|c|c|c|c|c|}
\hline $\begin{array}{c}\text { Case } \\
\text { number }\end{array}$ & Age & Sex & $\begin{array}{c}\text { Paroxysmal } \\
\text { dyspnœa }\end{array}$ & $\begin{array}{c}\text { P.A. } \\
\text { pressure } \\
\text { (mm. Hg) }\end{array}$ & $\begin{array}{l}\text { "Wedge" } \\
\text { mean } \\
\text { pressure } \\
(\mathrm{mm} . \mathrm{Hg})\end{array}$ & $\begin{array}{l}\text { Radiological } \\
\text { septal } \\
\text { lines }\end{array}$ & $\underset{\substack{\text { Maximum } \\
\text { size } \\
(\mathrm{mm} .)}}{\mid}$ & $\begin{array}{c}\text { Zones } \\
\text { involved }\end{array}$ \\
\hline 1 & 35 & F & - & $145 / 50$ & - & + & $2 \cdot 5$ & $\begin{array}{l}\text { RLZ } \\
\text { LLZ } \\
\text { LMZ }\end{array}$ \\
\hline 2 & 29 & $\mathbf{M}$ & - & $120 / 50$ & 42 & + & $3 \cdot 0$ & $\begin{array}{l}\text { RLZ } \\
\text { LLZ }\end{array}$ \\
\hline 3 & 36 & F & + & 90 mean & 35 & + & $5 \cdot 0$ & $\begin{array}{l}\text { RLZ } \\
\text { LLZ }\end{array}$ \\
\hline 4 & 34 & F & - & 90 mean & - & + & $6 \cdot 5$ & $\begin{array}{l}\text { RLZ } \\
\text { RMZ } \\
\text { LLZ }\end{array}$ \\
\hline 5 & 41 & F & - & $92 / 40$ & 22 & + & $6 \cdot 0$ & $\begin{array}{l}\text { RLZ } \\
\text { LLZ }\end{array}$ \\
\hline 6 & 27 & $\mathbf{M}$ & - & $85 / 50$ & 30 & + & $4 \cdot 0$ & $\begin{array}{l}\text { Diffuse } \\
L=R\end{array}$ \\
\hline 7 & 38 & $\mathbf{M}$ & - & $80 / 35$ & 24 & - & $2 \cdot 5$ & $\begin{array}{l}\text { RLZ } \\
\text { LLZ }\end{array}$ \\
\hline 8 & 28 & $\mathbf{M}$ & - & $70 / 35$ & 25 & - & $4 \cdot 0$ & $\begin{array}{l}\text { RLZ } \\
\text { LMZ }\end{array}$ \\
\hline 9 & 37 & M & - & $65 / 35$ & 24 & + & $2 \cdot 5$ & $\begin{array}{l}\text { RLZ } \\
\text { LLZ }\end{array}$ \\
\hline 10 & 29 & F & - & $55 / 20$ & 24 & + & 3.0 & $\begin{array}{l}\text { RLZ } \\
\text { LLZ } \\
\text { Mid-zones }\end{array}$ \\
\hline 11 & 30 & F & + & $55 / 25$ & 20 & + & 2.5 & $\begin{array}{l}\text { RLZ } \\
\text { LLZ }\end{array}$ \\
\hline 12 & 26 & $\mathbf{M}$ & + & $50 / 20$ & 24 & + & $5 \cdot 0$ & $\begin{array}{l}\text { RLZ } \\
\text { LLZ }\end{array}$ \\
\hline 13 & 45 & $\mathbf{M}$ & + & $50 / 15$ & 10 & + & $3 \cdot 0$ & $\begin{array}{l}\text { Diffuse } \\
\mathbf{R}=\mathbf{L}\end{array}$ \\
\hline 14 & 32 & F & - & $50 / 25$ & 25 & - & $3 \cdot 0$ & $\begin{array}{l}\text { RLZ } \\
\text { LLZ }\end{array}$ \\
\hline 15 & 43 & $\mathbf{F}$ & - & $45 / 15$ & 22 & - & $3 \cdot 5$ & RLZ \\
\hline 16 & 47 & $\mathbf{M}$ & - & $38 / 20$ & 16 & + & $4 \cdot 0$ & $\begin{array}{l}\text { RLZ } \\
\text { LLZ }\end{array}$ \\
\hline 17 & 24 & $\mathbf{M}$ & - & $35 / 25$ & 21 & + & $2 \cdot 0$ & $\begin{array}{l}\text { RLZ } \\
\text { LMZ }\end{array}$ \\
\hline 18 & 45 & F & + & $35 / 15$ & 10 & - & $3 \cdot 0$ & $\begin{array}{l}\text { RLZ } \\
\text { RMZ } \\
\text { LLZ } \\
\end{array}$ \\
\hline
\end{tabular}


TABLE II-cont.

Details of the Clinical, Hemodynamic, and Radiological features in the Group of Patients With Ossific NODULES

\begin{tabular}{|c|c|c|c|c|c|c|c|c|}
\hline $\begin{array}{c}\text { Case } \\
\text { number }\end{array}$ & Age & Sex & $\begin{array}{c}\text { Paroxysmal } \\
\text { dyspnoea }\end{array}$ & 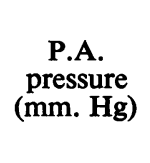 & $\begin{array}{c}\text { "Wedge" } \\
\text { mean } \\
\text { pressure } \\
(\mathrm{mm} . \mathrm{Hg})\end{array}$ & $\begin{array}{l}\text { Radiological } \\
\text { septal } \\
\text { lines }\end{array}$ & 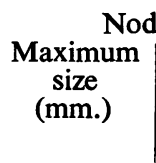 & $\begin{array}{l}\text { Zones } \\
\text { Involved }\end{array}$ \\
\hline 19 & 50 & $\mathbf{M}$ & + & $27 / 15$ & 6 & + & $3 \cdot 5$ & $\begin{array}{l}\text { RLZ } \\
\text { LLZ }\end{array}$ \\
\hline 20 & 27 & $\mathbf{M}$ & - & $25 / 10$ & - & - & 3.5 & $\begin{array}{l}\text { RLZ } \\
\text { LLZ }\end{array}$ \\
\hline 21 & 32 & $F$ & + & - & - & - & $2 \cdot 0$ & RLZ \\
\hline 22 & 52 & $\mathbf{M}$ & + & - & - & - & $3 \cdot 5$ & $\begin{array}{l}\text { RLZ } \\
\text { LLZ }\end{array}$ \\
\hline 23 & 31 & $\mathbf{F}$ & - & - & - & - & $7 \cdot 0$ & $\begin{array}{l}\text { RLZ } \\
\text { LLZ }\end{array}$ \\
\hline 24 & 28 & $F$ & - & - & - & - & $2 \cdot 0$ & $\begin{array}{l}\text { RLZ } \\
\text { LLZ }\end{array}$ \\
\hline 25 & 47 & $\mathbf{M}$ & + & - & - & + & 2.0 & $\begin{array}{l}\text { Diffuse } \\
R=L\end{array}$ \\
\hline 26 & 35 & $\mathrm{~F}$ & + & - & - & + & $4 \cdot 0$ & $\begin{array}{l}\text { RLZ } \\
\text { LLZ }\end{array}$ \\
\hline 27 & 36 & $\mathbf{M}$ & + & - & - & + & 4.0 & $\begin{array}{l}\text { RLZ } \\
\text { RMZ } \\
\text { LLZ }\end{array}$ \\
\hline
\end{tabular}

P.A.=Pulmonary Artery, R.L.Z.=Right lower zone. R.M.Z.=Right mid zone. L.L.Z.=Left lower zone. L.M.Z.=Left mid zone.

or the mean pulmonary wedge pressure.* Only two films of the series showed hæmosiderosis $(7 \cdot 4$ per cent). In the whole group of 204 patients it was present in 24 (11.8 per cent).

Mitral valve calcification was not sought for in all patients by fluoroscopy or tomography of the heart. Therefore, to assess the relative frequency of valve calcification, a group of 164 patients subjected to mitral valve surgery was studied as a control group, the operating surgeon classifying valve calcium into three grades of severity if it was present on palpation at operation.

The results were compared with 18 patients with ossific nodules who had an operation, in whom it was possible to assess the valve in a similar fashion (Table III). Wood (1954) found that 28 per cent of his patients had surgically detectable calcium at operation, and Goodwin et al. (1955) found it to be present in 37 per cent of their surgical series. Our figure of 32 per cent (Table III) agrees reasonably well with these previous findings. Valve calcium was present in 39 per cent of the ossific nodule group, which, therefore, shows no significantly higher incidence of calcification. Men, however, in the group as a whole have almost twice the frequency of valve calcification and this also applied to patients with ossific nodules.

Diffusely scattered small calcified lesions in the lung fields may be due to a variety of disorders. Calcified miliary tuberculosis is usually more diffuse than are ossific nodules and affects all lung zones. Histoplasmosis and coccidioidomycosis cause similar lesions of a diffuse nature. Pulmonary alveolar microlithiasis produces a fairly typical radiological picture. Sarcoidosis, pneumoconiosis, hæmosiderosis, and bilharziasis also need to be considered. Most of these lesions

* Correlation coefficient ( $r$ ), and significance $(p)$ : Pulmonary systolic pressure and nodule size: Pulmonary systolic pressure
$\mathrm{r}+0.22, \mathrm{p}<0.4:>0.3$

Pulmonary systolic pressure and number of zones affected:

Mean capillary wedge pressure and nodule size:

$\mathrm{r}+0.18, \mathrm{p}<0.5:>0.6$ $+0 \cdot 10, \mathrm{p}<0 \cdot 7:>0.6$

Mean capillary wedge pressure and number of zones affected: $\mathrm{r}-0.14, \mathrm{p}<0.6:>0.5$ 
TABLE III

Valve Calcification Assessed and Graded at Operation

\begin{tabular}{l|c|c|c|c|c|c}
\hline & \multicolumn{3}{|c|}{ (Whole group) } & \multicolumn{2}{c}{ (Ossific nodule group) } \\
\hline Men & Women & Total & Men & Women & Total \\
\hline No valve calcification _. & 21 & 90 & 111 & 3 & 8 & 11 \\
\hline Slight valve calcification .. & 3 & 10 & 13 & 1 & 0 & 1 \\
\hline Moderate valve calcification & 3 & 4 & 7 & 0 & 1 & 1 \\
\hline \begin{tabular}{l} 
Severe valve calcification .. \\
\hline Total patients .. ..
\end{tabular} & 19 & 14 & 33 & 4 & 1 & 5 \\
\hline Number with valve calcium & 25 & 118 & 164 & 8 & 10 & 18 \\
\hline Percentage with valve calcium & $54 \cdot 3$ & 28 & 53 & 5 & 2 & 7 \\
\hline
\end{tabular}

Three grades of calcification as assessed by the surgeon at operation. Corresponding to, slight; moderate; and severe.

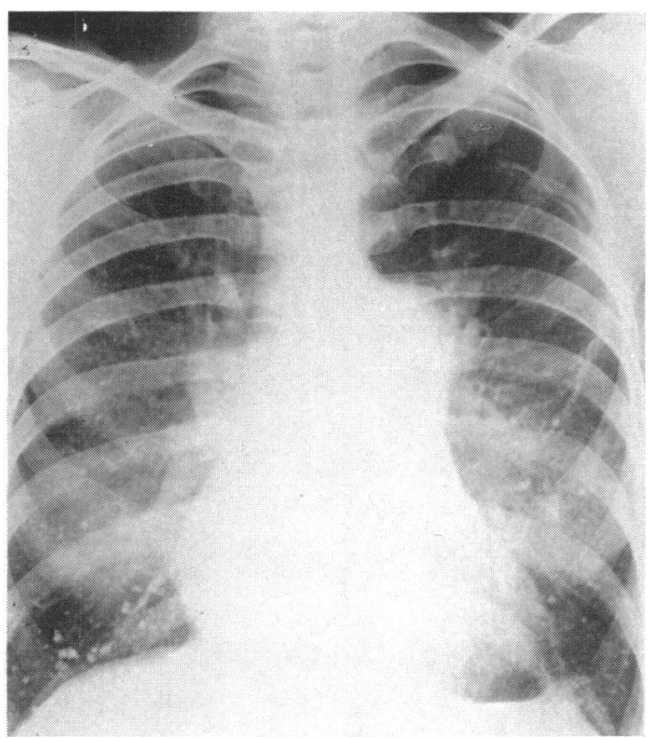

FIG. 1.-Case 4. Postero-anterior radiograph showing the distribution of the nodules in both lower and mid-zones, and particularly at the right base. Maximum diameter of the nodules is $6.5 \mathrm{~mm}$. There is radiological evidence of pulmonary arterial hypertension and septal lines are also present. (Film taken three years after mitral valvotomy.)

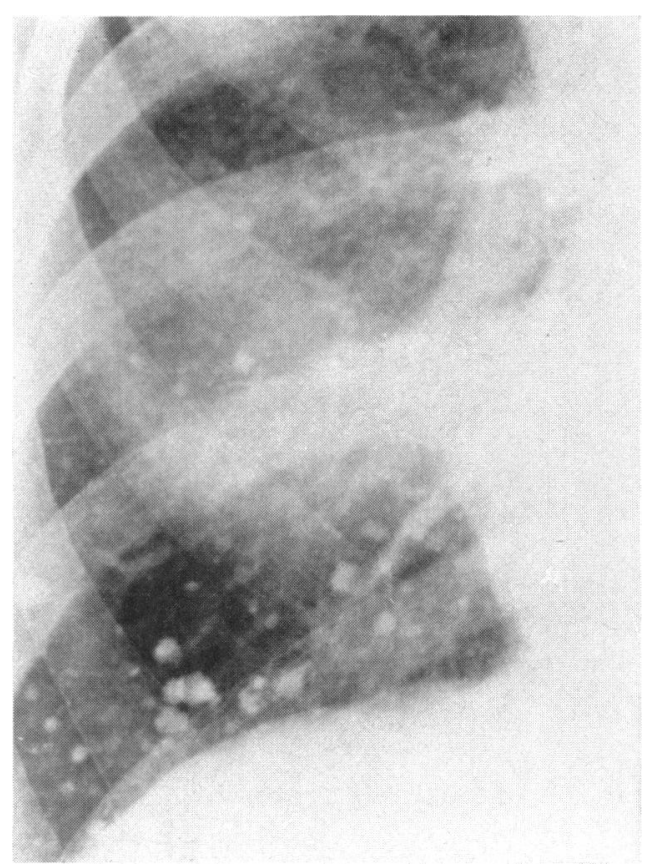

FIG. 2.-Enlargement of the right base from Case 4 showing greater detail.

are in fact much less sharply defined than ossific nodules and in the presence of mitral valve disease there is rarely any difficulty in diagnosis. The nodules were normally most conspicuous in the lower zones and particularly at the right base (Fig. 1 and 2). Occasionally they were diffusely distributed throughout the lung fields but tended to thin out towards the apices, which were only rarely affected. Their size varied from $2 \mathrm{~mm}$. diameter to a maximum of $8 \mathrm{~mm}$. 


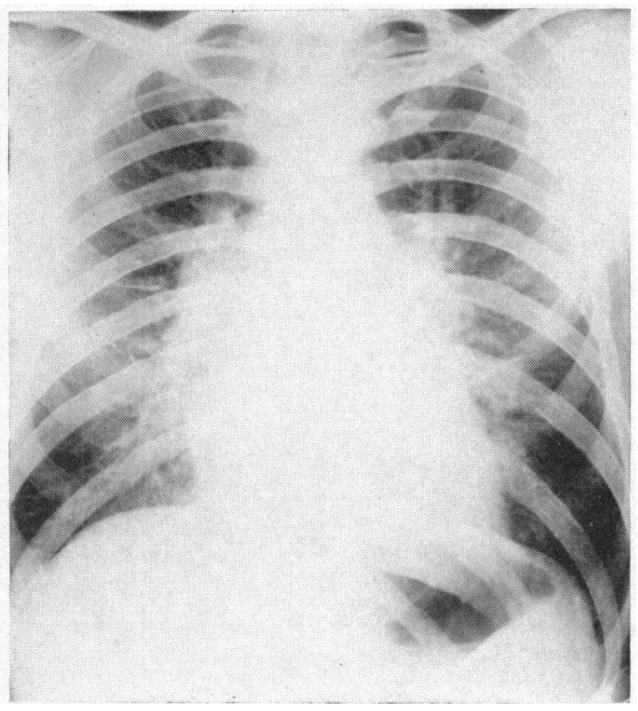

Fig. 3.-Case 9, September 1956, showing pulmonary interstitial œdema without radiologically visible ossific nodules.

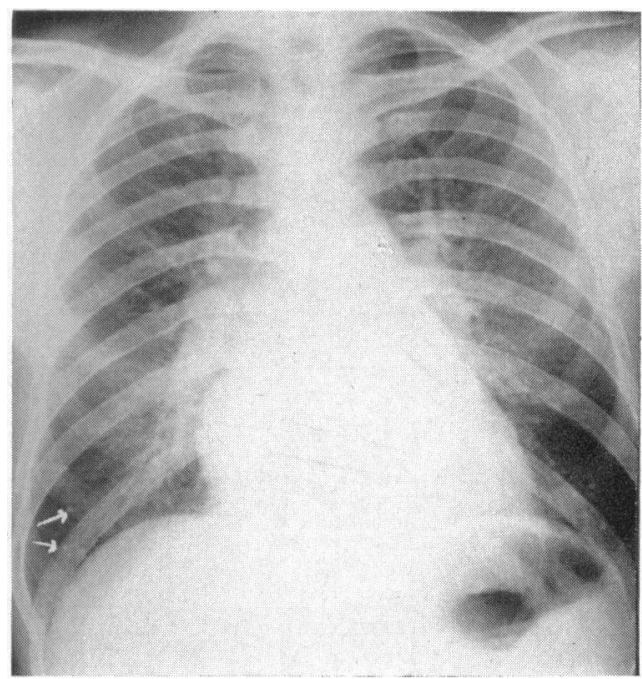

FIG. 4.-The same patient as in Fig. 3. February 1960, showing the development of nodules during a period of over three years. (Arrowed.)

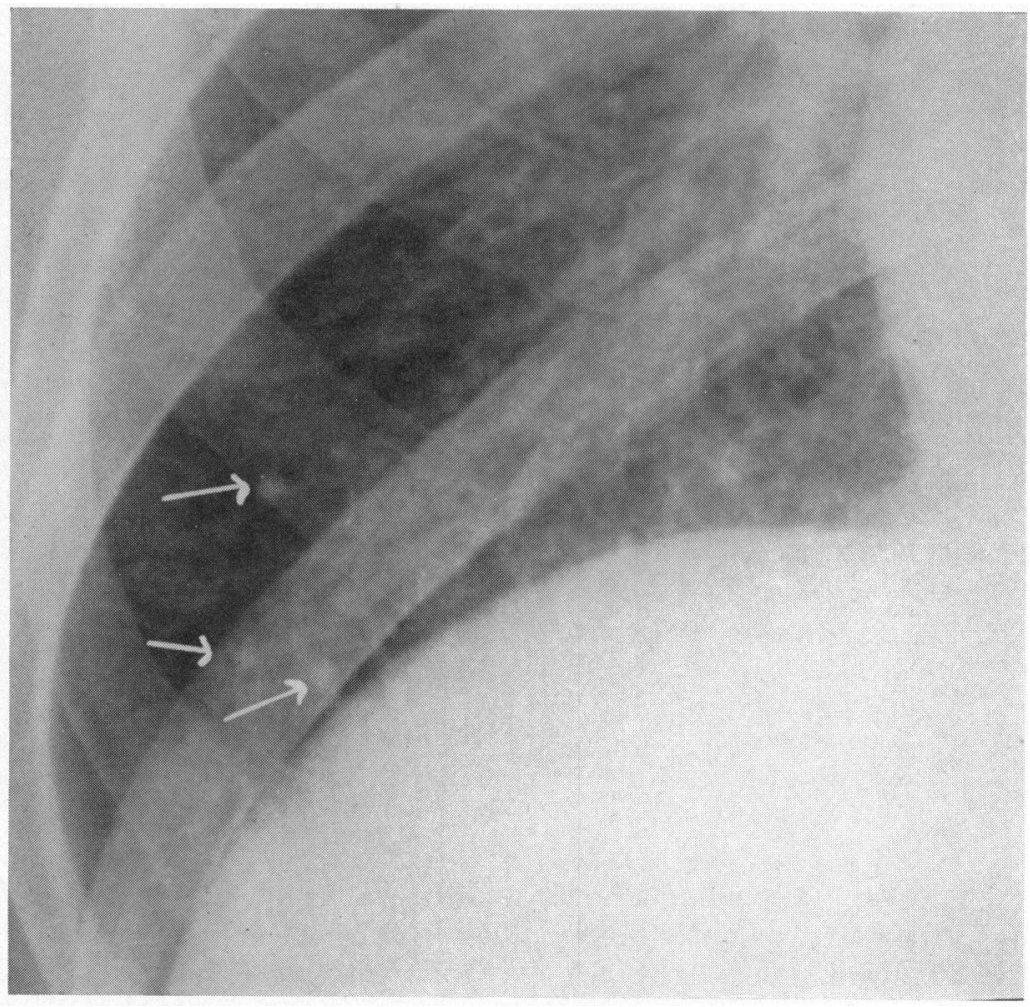

FIG. 5.-Enlargement of the right base of lung shown in Fig. 4. 
It is probable that the rate of development of the nodules is very slow and we tried to assess the rate of progression of the nodules from serial films. The appearance varies a good deal with the radiological technique, which had not been uniform over the several years between different films, but although the length of time between the films varied from one to five and a half years, there was little apparent significant change in any of our patients.

Figures 3 and 4 show the development of nodules over a period of three years (Case 9). This patient died and the presence of ossific nodules was confirmed at autopsy (Fig. 5 and 6). In the paper by Whittaker et al. (1955) their Case 3 shows moderate progression over a period of three years, but none of our own patients with established ossific nodules showed this degree of change. The nineteen patients who have been operated on have been followed up for from one to four years, without any showing radiological regression of their lesions.

\section{Pathology}

The nodules are yellowish-white and of bony consistency, varying in size from two to eight millimetres. Usually they are rounded and often mulberry shaped. They are easily shelled out of the lung and specimens need to be handled carefully in order to obtain histological sections.

Microscopically the bone is lamellar and mature in type and the alveolar walls are closely applied to the surface of the bone, which appears to be intra-alveolar. Osteocytes are scattered diffusely throughout the bone.

At the periphery of the nodules osteoid tissue has been found. There was no evidence of calcification without bone formation and the bone appears to be formed by calcium deposition in a matrix of osteoid tissue. Elkeles and Glynn (1946) found that the framework of the lung was incorporated in the developing bone, and demonstrated continuity of the elastic tissue of the surrounding lung through into the bone of the nodule. We were unable to demonstrate this in our own sections even though the larger nodules clearly overlap several adjacent lung lobules. Neither did any show the presence of bone marrow which has also been described. Hæmosiderin has not been conspicuous in any of the sections, which agrees with the previous observations of Whittaker $e t$ al. (1955) and Fleming and Robinson (1957).

\section{Discussion}

The radiological findings in our series of 27 patients with pulmonary ossific nodules and mitral valve disease are similar to those described by numerous other authors in respect of size, appearance, and distribution. On this basis we feel justified in considering them to be composed of osseous tissue although biopsy proof was obtained in only one case.

Although small groups of cases of ossific nodules have been reported, no survey of the incidence of these nodules has been carried out so far as we are aware. There is a brief comment in a paper by McAffee and Biondetti (1957) that they were present radiologically in 10 per cent of 150 consecutive mitral valvotomy patients, but no further information is given. This agrees well with our own assessment of their presence in 13 per cent of over 200 patients with mitral valve disease.

Our cases are divided equally between the sexes, which is rather a different ratio to the overwhelmingly large number of cases in men previously reported, although when the relative incidence is worked out, nodules were present in 24.5 per cent of the men and in only 8.8 per cent of the women. Thus they are three times as common in men.

At the beginning of this paper we mentioned a group of 9 patients classified as having "doubtful" nodules because one of the three observers dissented. Without a biopsy or a prolonged follow up of this group there is no way of achieving a decisive answer.

In Case 6 of Whittaker et al. (1955) and Case 3 of Wilson et al (1959) ossific nodules were found on biopsy and at autopsy respectively, although they were not visible on the chest films. We have also found ossific nodules at autopsy in the lungs of eight patients who had moderately severe mitral stenosis. These patients have died in recent months and although their chest films showed no evidence of nodules, the lungs were carefully sectioned and examined post 


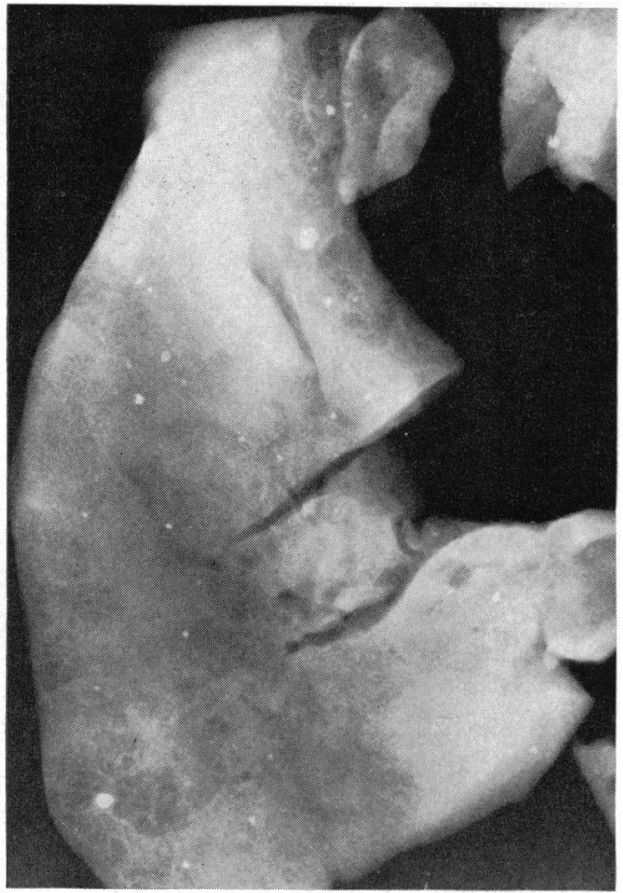

FiG. 6.-Post-mortem contact X-ray of 1 centimetre lung slice taken from the lower lobe of Case 9. This approximately corresponds to the area shown in Fig. 5 and shows several ossific nodules.

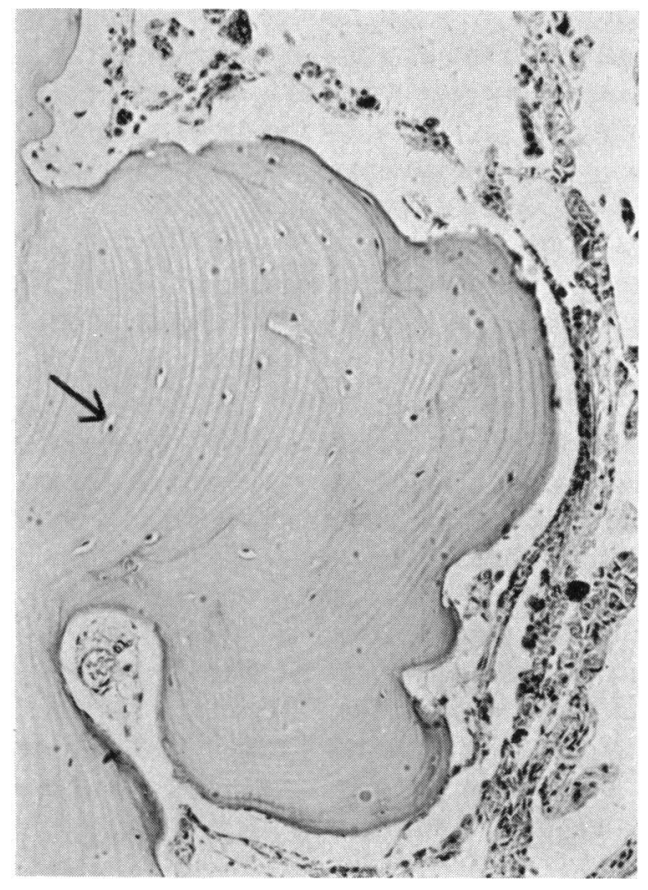

FIG. 7.-Low power view of part of an ossific nodule, showing the lamellar bone and osteocytes (arrow). (H. \& E., $\times 50$.)

mortem with the aid of contact radiography of thin slices of lung, together with histological examination of suspicious areas. These observations suggest that ossific nodules are much more frequent than has previously been realized and, in fact, they may be found in a high proportion of the lungs from patients with mitral valve disease if carefully sought for at autopsy. Lendrum et al. (1950) found ossific nodules in 3 out of 26 cases examined histologically post mortem although there is no information regarding the radiological findings in these cases.

Hitherto only the most florid maifestations have received attention because they are visible radiologically. It is perhaps not too far-fetched to draw an analogy with hæmosiderosis, since the work of Lendrum et al. (1950) showed this lesion to be not uncommon radiologically and very common indeed on histological section, if appropriate staining of the lung was undertaken in cases of mitral valve disease.

In assessing our group of patients with pulmonary ossification, we compared several factors with the incidence in the group of 204 patients as a whole to see whether this would shed any light on the ætiology. There was no correlation with age, symtomatology, cardiac rhythm, heart size, pulmonary arterial pressure, or the presence of hæmosiderosis or valve calcification (Tables II and III).

Twenty-four out of the 27 patients had evidence of significant pulmonary venous hypertension using one or more of three factors thought to be criteria of its presence. That is, a history of paroxysmal nocturnal dyspnœa, the presence of septal lines on the chest film, and a pulmonary wedge mean pressure of $20 \mathrm{~mm}$. $\mathrm{Hg}$ or more. Two of the remaining three patients came to operation because of severe breathlessness and both had "critical" mitral stenosis (Wood, 1954). Thus, a raised venous pressure may well be inferred on clinical grounds. A high pulmonary artery pressure 
in mitral stenosis is almost invariably associated with considerable pulmonary venous hypertension, although it is not proportionately related to it. Fleming and Robinson (1957) noted the presence of septal lines in all their cases, although none of them gave a history suggestive of pulmonary venous congestion, and we would agree with their statement that septal lines in mitral valve disease are evidence of a previously raised pulmonary venous pressure. Transient lines are probably due to odema of the inter-lobular septa (Rossall and Gunning, 1956) while hæmosiderin deposition or fibrous thickening may be responsible for persistent septal lines (Fleischner and Reiner, 1954).

In a disorder like mitral stenosis, where there are profound and complicated changes in the pulmonary circulation it does not follow that there is a direct relationship between two factors because they change simultaneously. The association of ossific nodules with intra-cardiac calcification has been previously noted but, in fact, is probably due to both developing in the same circumstances. Valve calcification as assessed at operation is no more common in the nodule cases than in the group as a whole (Table III) and both factors appear to be more common in men.

The ossification in intra-alveolar (Elkeles and Glynn, 1946; Lendrum et al., 1950; Fleming and Robinson, 1957) and our own histological sections bear this out (Fig. 7). Lendrum et al. (1950) suggested that the ossification develops in areas of intra-alveolar odema, and although their views on the mechanism of the production of pulmonary odema in mitral valve disease are open to criticism, this in no way precludes the possibility of the pulmonary œdema being the site of formation of the ossific nodules. Hæmosiderosis was less common radiologically in the group of patients with nodules than in the group as a whole, and this finding, together with the presence of only small amounts of hæmosiderin in lung sections from our eight autopsy cases with histologically proven nodules, suggests that hæmosiderosis is not the precursor of nodule formation, as suggested by Lawson (1949) and Ellman and Gee (1951). Hæmosiderosis was also inconspicuous in the cases reported by Whittaker et al. (1955) and Fleming and Robinson (1957).

In mitral stenosis, pulmonary œdema is closely related to the pulmonary venous pressure and hence the evidence of its significant elevation in nearly all our patients is indirect evidence supporting the hypothesis of Lendrum et al. (1950). All the patients reported by Fleming and Robinson (1957) had septal lines present on their chest films.

Severe pulmonary arterial hypertension, although present in several of our patients, does not seem to be necessary for the development of nodules. Of 20 patients, on whom catheterization studies had been performed, there were 9 with a pulmonary arterial systolic pressure of $50 \mathrm{~mm}$. $\mathbf{H g}$ or below, and 4 with a normal pulmonary artery pressure. Furthermore, the size and frequency of the ossific nodules is not related to the pulmonary arterial pressures.

Nodules vary from 2 to $8 \mathrm{~mm}$. in diameter and rarely show progressive change in serial films viewed over a period of several years. None have been reported with a diameter of more than $10 \mathrm{~mm}$. This suggests that there is a limited upper size to these lesions and it is possible that their size is limited by that of the secondary pulmonary lobules, which are surrounded by a framework of connective tissue and lymphatic vessels (Miller, 1947).

Calcium salts are normally deposited only in bone and teeth but pathological calcification is frequent in soft tissues and as concretions in excretory or secretory passages. Apart from calcium deposition in dead or degenerating tissues it is also known to occur in tissues that lose hydrogen ions and alter their $p \mathrm{H}$. This occurs in the stomach, renal tubules, and lung alveoli. Metastatic calcification develops in generalized disturbances of calcium metabolism, for example in hyperparathyroidism. Studies of calcium metabolism were not carried out in any of our patients as there were no clinical reasons for suspecting a disorder of calcium metabolism. The only such studies carried out in patients with ossific nodules were those of Pezzuoli et al (1955) who reported biochemical details in two patients, and their investigations showed no abnormality. Alveolar calcification has been described in hyperparathyroidism and inflammatory lesions of the lung (Barnard, 1946).

Pathological ossification often develops in areas of dystrophic calcification but this does not seem to be the sequence of events in the development of ossific nodules. The nodules develop as true 
bone in relation to osteoblasts without any preceding calcification, and they are in fact areas of calcified osteoid tissue.

All the information available from our own study and from other papers favours the view that ossification develops in areas of pulmonary intra-alveolar œdema. The pulmonary œdema itself depends on the presence of pulmonary capillary hypertension secondary to pulmonary venous hypertension. That the nodules are more common in the lower lobes may depend on the presence of a higher pulmonary venous pressure in the lower lobes due to a hydrostatic effect (Doyle et al., 1957; Grainger, 1958). Although acute pulmonary adema tends to be perihilar, chronic pulmonary odema is more common in the lower zones (Jackson, 1951).

Only two patients in the series showed clinical evidence of dominant mitral regurgitation. Pulmonary venous hypertension usually appears relatively late in the natural history of mitral regurgitation and is often due to left ventricular failure. Its duration is, therefore, less prolonged than in dominant mitral stenosis (Wood, 1956). This may be the main reason for the very few reported cases of ossific nodules associated with mitral regurgitation.

Ossific nodules have never been reported in patients with pulmonary arterial hypertension due to other causes, such as congenital heart disease, cor pulmonale, or primary pulmonary hypertension, where the pulmonary venous pressure is not increased. Neither have they been observed in other disorders with a raised pulmonary venous pressure such as cor triatriatum or left atrial myxoma, in which they theoretically could develop if the hypothesis of underlying pulmonary adema is a correct one. Such cases are extremely rare so that it is not surprising that ossific nodules have not so far been reported. We have recently had the opportunity of examining the lungs of a woman aged 39 years, who died from recurrent pulmonary odema and congestive cardiac failure due to a left atrial myxoma. The lungs were examined by the technique described above and ossific nodules were found to be present, although they were not visible radiologically. The chest film showed conspicuous septal lines. There was no evidence of rheumatic endocarditis in this patient and it seems reasonable to infer a causal relationship between the mechanically obstructed mitral valve with consequent pulmonary venous hypertension and the presence of ossific nodules.

Left ventricular failure, due to disorders such as hypertension, coronary artery disease, or aortic valve disease is usually of short duration and even with modern treatment is not likely to persist for more than two to three years. This time is probably too short for ossific nodules to develop.

\section{SUMMARY}

In a routine radiological survey of 204 patients with mitral valve disease, 27 patients $(13 \%)$ were found to have clearly defined pulmonary ossific nodules. They were present three times as often in men as in women, when allowance was made for the sex ratio in the series as a whole. They appear to be much more common than previously supposed, probably because attention has been focused on the more florid radiological appearances.

In addition, the lungs from eight patients with mitral stenosis examined carefully at autopsy were all found to contain ossific nodules despite their absence radiologically, again favouring the view that nodules are common.

These cases were reviewed with reference to clinical findings, other radiological features, catheter studies, and the presence of valve calcification assessed at operation. There was no apparent relationship to age, symptomatology, cardiac rhythm, heart size, pulmonary arterial hypertension, hæmosiderosis, or valve calcification. The most significant finding was pulmonary venous hypertension, which was present in 24 of the 27 patients with nodules, using one or more of three criteria of its presence: that is, a history of paroxysmal dyspnœa, septal lines on the chest film, and a pulmonary wedge mean pressure of $20 \mathrm{~mm}$. $\mathrm{Hg}$ or more. Pulmonary venous hypertension was inferred in 2 of the 3 others who had an operation because of progressive symptoms.

The nodules were shown histologically to be intra-alveolar and composed of lamellar bone formed on a basis of osteoid tissue, there being no evidence of calcification preceding the bone 
formation. It is suggested that the ossific nodules develop in areas of subacute pulmonary intraalveolar œdema, indirectly due to a raised pulmonary venous pressure. The nodules are more numerous in the lower lobes, and this may depend on a hydrostatic effect producing a relatively higher pressure than in the upper lobes.

A patient with a left atrial myxoma with ossific nodules is described; and this is presented as additional evidence favouring the hypothesis that pulmonary venous hypertension is the critical factor in the pathogenesis of the nodules.

In mitral valve disease and particularly in mitral stenosis there is a sufficiently prolonged period of pulmonary venous hypertension for the necessary pathological changes to develop.

We are indebted to Dr. E. Noble Chamberlain, Dr. E. Wyn Jones and Dr. C. S. McKendrick for allowing us access to their patients in the Regional Cardiac Centre, Sefton General Hospital, and to Mr. L. J. Temple for his careful notes recorded at operations on these patients.

Dr. J. A. Ross has allowed us to use the material collected in the Department of Radiodiagnosis at Sefton General Hospital; Dr. Roger Chapman was kind enough to help with the pathological and histological studies, and Dr. C. M. Miller permitted us to use the data from the case of left atrial myxoma.

We would also like to record our gratitude to the technical staffs in the Cardiological and Radiological Departments, and to Mr. Alan Scott for the preparation of the histological sections and microphotographs.

\section{REFERENCES}

Barnard, W. G. (1946). J. Path. Bact., 58, 625.

Carmichael, J. H. E., Julian, D. G., Jones, G. P., and Wren, E. M. (1954). Brit. J. Radiol., $27,381$.

Daugavietis, H. E., and Mautner, L. S. (1957). Arch. Path., 63, 7.

Davies, L. G., Goodwin, J. F., Steiner, R. E., and Van Leuven, B. D. (1953). Brit. Heart J., $15,393$.

Doyle, A. E., Goodwin, J. F., Harrison, C. V., and Steiner, R. E. (1957). Brit. Heart J., 19, 353.

Elkeles, A., and Glynn, L. E. (1946). J. Path. Bact., 58, 517.

Ellman, P., and Gee, A. (1951). Brit. med. J., 2, 384.

Fleischner, F. G., and Reiner, L. (1954). New Eng. J. Med., 250, 900.

Fleming, H. A., and Robinson, C. L. N. (1957). Brit. Heart J., 19, 532.

Goodwin, J. F., Hunter, J. D., Cleland, W. P., Davies, L. G., and Steiner, R. E. (1955). Brit. med. J., $2,573$.

Grainger, R. G. (1958). Brit. J. Radiol., 31, 201.

- and Hearn, J. B. (1955). J. Fac. Radiol. Lond., 7, 66.

Grishman, A., and Kane, I. J. (1945). Amer. J. Roentgenol., 53, 575.

Jackson, F. (1951). Brit. Heart J., 13, 503.

Lawson, H. M. (1949). Brit. med. J., 1, 433.

Lendrum, A. C., Scott, L. D. W., and Park, S. D. S. (1950). Quart. J. Med., 19, 249.

McAfee, J. G., and Biondetti, P. (1957). Amer. J. Roentgenol, 78, 213.

Miller W. S. (1947). The Lung. 2nd Edition (Charles C. Thomas, Springfield, Illinois).

Pezzuoli, G., Gasparini, V., and Folli, G. (1955). Pr. med., 63, 972.

Rossall, R. E., and Gunning, A. J. (1956). Lancet., 1, 604.

Salinger, H. (1932). Fortshr Rontgenstr, 46, 269.

Short, D. S. (1955). Brit. Heart J., 17, 33.

Steiner, R. E., and Goodwin, J. F. (1954). J. Fac. Radiol. Lond., 5, 167.

Wagner, E. (1859). Arch. Physiol. Heilk., 35, 411.

Wells, H. G., and Dunlap, C. E. (1943). Arch. Path., 35, 420.

Whittaker, W., Black, A., and Warrack, A. J. N. (1955). J. Fac. Radiol. Lond., 7, 29.

Wilson, W. R., Sasaki, R., and Johnson, C. A. (1959). Circulation, 19, 323.

Wood, P. (1954). Brit. med. J., 1, 1051.

. (1956). Diseases of the Heart and Circulation. 2nd Edition (Eyre and Spottiswoode, London). 